\title{
Local people's perception and awareness of climate change: a case study from community forests in Lamjung District, Western Nepal
}

\begin{abstract}
N. Dhungana ${ }^{1 *}$, N. Silwal ${ }^{2}$, S. Upadhaya ${ }^{3}$, S. K. Regmi ${ }^{4}$ and S. Adhikari ${ }^{5}$
Climate change has negatively impacted the underdeveloped and developing countries including Nepal due to low adaptive capacity and higher dependency in agriculture. Forests are important component of the lives and livelihoods of the community in Nepal, which can offer an important source of climate-resilient livelihood. It is crucial to know the fact that climate change was in the past, which will continue to change in the future. It is essential to understand how communities perceive and adapt to climate change. A study was carried out in Kirepani, Jagreni and Kalika Community Forest User Groups (CFUGs) in Lamjung District with an objective of assessing their perceptions on impacts of climate change. The survey was carried out in 62 households along with participatory appraisal to understand the perception of local people on climate change and its impacts. Focus group discussion was held in each CFUG. Climatic data of 29 years (1987-2015) acquired from Khudi, Kuncha and Gharedgunga metereological stations and analysed to supplement the results. Data were analysed using MS-Excel as major computer software and presented as table, trend lines and graphs. The study showed that the locals correctly perceived change in temperature, unpredictable occurrence of rainfall and increased incidence of change in crops phenology, an increase in drought.Based on the perceptions of the community forest users, climate change has affected the biodiversity and societal system differentially. Drought has higher impact to the people affecting their lives and livelihoods. They perceived that the increase in drought, floods, landslide have affected their lives and livelihoods. The results revealed that minimum temperature was increased at the rate of $0.01^{\circ} \mathrm{C}$ per year whereas the maximum temperature was increased by $0.056^{\circ} \mathrm{C}$ per year. From the rainfall data of Khudi meteorological station, it was found that annual rainfall was highly decreased at the rate of $25.8 \mathrm{~mm}$ per year, which alarms for more disaster such as drought and fire in the area. Our findings suggest that for the innovative climate change adaptation planning and policy it is crucial to incorporate and acknowledge the role of community forest in climate change adaptation.
\end{abstract}

Key words: CFUGs, climate change, impact, perception

I ntergovernmental panel on climate change report (2007) states that climate change is universally accepted fact and is already having discernible impacts. Increasing Green House Gases (GHGs) emission has contributed to increasing atmospheric temperature. The available

data shows that atmospheric air temperature has increased by $0.85^{\circ} \mathrm{C}$ from 1880 to 2012 . It has been estimated that it could be increased as much as $6.4^{\circ} \mathrm{C}$ on an average during the $21^{\text {st }}$ century (IPCC, 2014). South Asian countries including Nepalare already experiencing climate change

1 CARE Nepal, Country Office, 4/288 - SAMATA Bhawan, Dhobighat, P.O. Box 1661, Lalitpur, Nepal.

* E-mail: nabindhungana.2007@gamil.com

2 Institute of Forestry, Pokhara Campus, Pokhara, Nepal.

3 Integrative Conservation of Nature and Forestry, Warnell School of Forestry and Natural Resources, The University of Georgia, Athens GA USA.

4 Winrock International Nepal, House \# Kha 194, P.O. Box 8975, Sanepa, Lalitpur, Nepal

5 Department of Forests, District Forest Office, Chitwan 
and increasing frequency of climate-related hazards, such as droughts, floods, and landslides. Nepal is one of the most vulnerable regions to climate change and climate variance in the world not only because of more rapid increase in temperature but also because of the inhabitants being among the world's poorest groups (Smith et al., 2000). Nepal has experienced an average maximum annual temperature increase of $0.06^{\circ} \mathrm{C}$ per year which is higher in the mountains than other places of Nepal (Practical Action Nepal, 2009; MoE, 2011). Despite having only $0.4 \%$ of the global population in Nepal, and being responsible for only $0.025 \%$ of GHGs emissions in the world, it is likely that Nepal will be affected disproportionately from increasing atmospheric temperature changes in the annual rainfall and longer droughts (MoE, 2011).

Over one-third of the Nepalese population depends on climate-sensitive sectors like agriculture and forestry for their livelihood and has limited capacity to cope with disasters associated with climate change (Garg et al., 2007). The main adverse impacts of climate change in Nepal have been noticed in agriculture and food security, water resources, forest and biodiversity, health, tourism, and infrastructures (MoE, 2011) and its impacts differ in different sectors due to variability in local environmental conditions (Manandhar et al., 2011; Baral, 2011).

Forests have many functions and provide a range of goods and services such as climate regulations, protection from extreme events, carbon sequestration, and multiple provisioning ecosystem services such as food, wood, and fiber (Anderegg et al., 2013). Forests are important component of the lives and livelihoods system of the community in Nepal, which can offer an important basis for creating and safeguarding more climate-resilient livelihoods (Dahal, 2009). Nepal's forests are particularly important to the nation's rural in habitants, as most of their livelihoods depend upon them for daily survival (Stapp et al., 2016). Despite the important role, forests play in maintaining essential ecosystem services and contribute to climate regulation, globally we are losing forest cover where conversion of existing forestlands to agricultural land is increasing (Keenan et al., 2015). Climate change has also wide range of impacts on natural resources and biodiversity causing threats to forest conservation, species extinction and occurrence of pests and diseases (IPCC, 2007). Almost 75\% of the forestland is in high income and uppermiddle-income countries, but deforestation rates are higher in low-income countries (Keenan et al., 2015), where majority of the local people's livelihoodis depended on the forest.

The livelihoods of forest based people are projected to become increasingly more challenging due to climate change that results in loss of lands and productivity (Macqueen and Vermeulen, 2006 cited in Dahal, 2009). Forests being the important resources, the policy instruments are well adopted for their protection. The community forest is one of the most successful forest management models in Nepal. Stapp et al. (2015) found positive impacts of forest management policies and community level institutions in protecting forest cover. The study by Shrestha et al. (2018) suggested that districts with the larger number of community forests have a minimum loss in tree cover. There are 22, 266 (DoF, 2018) Community Forest UsersGroups (CFUGs) in Nepal and the community forests are being managed by them. These users groups not only manage the forest but equally contribute to community development, poverty reduction to climate change adaptation, etc. However, little attention has beengiven to documentingits role in climate change adaptation and mitigation. In this context, it is critical to understand the perceptions of the most affected, vulnerable users of the community forest. Likewise, developing country like Nepal lacks the scientific database on climate change in different levels including community forest; and the community forest sector lacks comprehensive study and knowledge gap on what actually forest-dependent communities perceive climate change. It is crucial to know the fact that climate change was in the past, which will continue to change in the future. It is essential to understand how communities perceive and adapt to climate change (Deressa et. al., 2011). To improve the ability of communities, households and individuals to adjust to ongoing and future climate change, it is crucial to improving understanding of the risk they face (Dhungana et al. 2017). We aim to assess anecdotal evidence and trends of climate change on the CFUGs and analyse the user's perceptions on climate change and its impacts in Lamjung district of Nepal. 
Table 1: Details of the CFUGs

\begin{tabular}{|l|c|c|l|}
\hline \multirow{2}{*}{ Description } & \multicolumn{3}{|c|}{ Kame of CFUGs } \\
\cline { 2 - 4 } Address & Besishahar- 5, Lamjung & $\begin{array}{c}\text { Besishahar- 4 and 5 } \\
\text { Lamjung }\end{array}$ & $\begin{array}{l}\text { Besishahar- 1 and 2 Lam- } \\
\text { jung }\end{array}$ \\
\hline Area (ha) & 47.34 & 83.87 & 63.27 \\
\hline Registration & 2052 B.S. & 2059 B.S. & 2052 B.S \\
\hline Housholds & 192 & 273 & 141 \\
\hline Total population & $\begin{array}{c}1008(483 \text { female and } \\
525 \text { male) }\end{array}$ & $\begin{array}{c}1473 \text { (688 female and } \\
785 \text { male) }\end{array}$ & $\begin{array}{l}833 \text { (427 male and } 406 \\
\text { female) }\end{array}$ \\
\hline Indigenous people & Gurung and Dalit & Dalit and Janajati & Gurung and Dalit \\
\hline Education status & $55 \%$ educated & $70 \%$ educated & $60 \%$ educated \\
\hline
\end{tabular}

\section{Materials and methods}

\section{Study area}

The study was carried out in Lamjung district (Fig. 1), which is located in Gandaki province of Nepal, extending from middle hill to the Northern Himalaya. It lies near to the middle of Nepal and its area is $1692 \mathrm{~km}^{2}$. The population of the district in 2011 was 167,724 (CBS, 2011). It is one of the biodiversity rich fragile hills of Nepal. Lamjung district is bordered with Gorkha district in the east, Kaski in the west, Manang in the north and Tanahu in the south. The latitude of the district is in a range of $28^{\circ} 03^{\prime}-28^{\circ} 30^{\prime} \mathrm{N}$, and longitude from $84^{\circ} 11^{\prime}-84^{\circ} 38^{\prime} \mathrm{E}$, and altitude ranges from $385 \mathrm{~m}$ to $8162 \mathrm{~m}$ from mean sea level. Lamjung is one of the nine districts classified by the National Adaptation Program of Action (NAPA) as highly vulnerable to climate changeregardingglacial lake outburst flood (GLOF) (MoE, 2010a). Likewise, the increasing rate of mean annual temperature and rainfall are $0.06^{\circ} \mathrm{C}$ and $13.25 \mathrm{~mm}$, respectively (MoE, 2010b). Due to mountain terrain with unstable geological structure, the district has a high risk of landslides

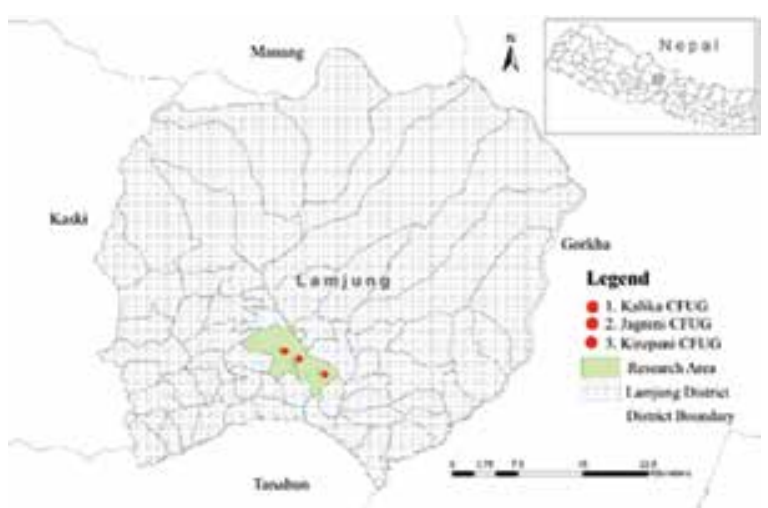

Fig.1. Map of Lamjung district showing study area and floods too. The district disaster preparedness and response plan identified flood/landslide, fire, earthquake and lightening as the major disaster risks in the district (DDRC, 2011).

Out of the seven CFUGs, three representative CFUGs (Kirepani, Jagreni and Kalika) (Table 1) were selected for the research purpose.

\section{Data collection}

Data were collected from primary and secondary sources. The questionnaire was designed to capture the perceptions of climate change and climaterelated events. The focus group discussion (FGD) was held in each CFUG. Thirty-two participants of the FGD were categorized on the basis of gender, caste and economic class (Table 2) for further analysis. Out of 616 households (HHs) in three CFUGs, 62 households (10.08\%) were selected randomly for primary data

Table 2: Details of the participants in focus group discussion

\begin{tabular}{|c|c|c|c|c|c|c|c|c|c|c|}
\hline \multirow[b]{2}{*}{$\begin{array}{c}\text { Location } \\
\text { of FGD }\end{array}$} & \multirow[b]{2}{*}{$\begin{array}{c}\text { Total } \\
\text { participants }\end{array}$} & \multicolumn{2}{|c|}{ Gender } & \multicolumn{3}{|c|}{$\begin{array}{c}\text { Caste/ } \\
\text { ethnicity }\end{array}$} & \multicolumn{4}{|c|}{ Well being } \\
\hline & & 离 & 总 & $\vec{E}_{\infty}$ & 昙 &  & 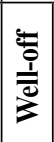 & 恶 & $\ddot{\grave{o}}$ &  \\
\hline \begin{tabular}{|l|} 
Kirepani \\
CFUG
\end{tabular} & 12 & 5 & 7 & 7 & 2 & 3 & 3 & 4 & 3 & 1 \\
\hline \begin{tabular}{|l|} 
Jagreni \\
CFUG
\end{tabular} & 9 & 3 & 6 & 3 & 3 & 3 & 2 & 4 & 1 & 3 \\
\hline $\begin{array}{l}\text { Kalika } \\
\text { CFUG } \\
\end{array}$ & 11 & 5 & 6 & 4 & 2 & 5 & 1 & 3 & 5 & 2 \\
\hline Total & 32 & 13 & 19 & 14 & 7 & 11 & 6 & 11 & 9 & 6 \\
\hline
\end{tabular}


Table 3: Disaggregate details of the respondents

\begin{tabular}{|c|c|c|c|c|c|c|c|c|c|c|c|}
\hline \multirow[b]{2}{*}{ Name of CFUG } & \multirow[b]{2}{*}{$\begin{array}{l}\text { Total no. of } \\
\text { households }\end{array}$} & \multicolumn{3}{|c|}{$\begin{array}{l}\text { Total } \\
\text { respondents }\end{array}$} & \multicolumn{3}{|c|}{ Caste/ethnicity } & \multicolumn{4}{|c|}{ Well being } \\
\hline & & $\sum^{\frac{0}{\pi}}$ & 莺 & हैं & 包 & 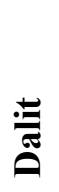 & & $\begin{array}{l}\frac{1}{0} \\
\frac{1}{\bar{c}} \\
\bar{c}\end{array}$ & 䍖 & 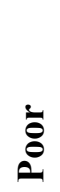 & 寄 \\
\hline Kirepani & 192 & 8 & 12 & 20 & 11 & 3 & 6 & 4 & 7 & 9 & 4 \\
\hline Jagreni & 273 & 11 & 16 & 27 & 18 & 4 & 5 & 3 & 6 & 6 & 5 \\
\hline Kalika & 151 & 9 & 6 & 15 & 8 & 3 & 4 & 1 & 7 & 7 & 3 \\
\hline Total & 616 & 28 & 34 & 62 & 37 & 10 & 15 & 8 & 20 & 22 & 12 \\
\hline
\end{tabular}

collection. But age criterion was used because young respondents would not have enough years of experiences to reflect properly on climate change (Manandhar et al., 2011). The respondents consisted of 59\% female and $61 \%$ male with an age range of 30 to 90 years. They are residing permanently in that area since more than 30 years. The respondents were categorized on the basis of caste, gender, agegroup, and economic class also (Table 3). The information related to understanding climate change (meaning and causes of drought, very less rainfall, warmer winter temperature, drying of water sources, polluted environment and unusual change of nature), perception on the indicators of climate change and seven statements, were captured from the respondents. The indicators are temperature, water sources, forest fire frequency, flood frequency, drought frequency and variation in river flow. The data on impacts of climate change were collected from the respondents by categorizing them into caste, gender, age-group and economic class.

Secondary data were collected through literature review and from different organizations. The meteorological data on temperature and rainfall (1987-2015) were acquired from three stations of Department of Hydrology and Meteorology (DHM) (Table 4).

Table 4: Climatic data of different stations

\begin{tabular}{|l|l|l|l|l|}
\hline Station Name & \multicolumn{1}{|c|}{ Type of data } & \multicolumn{1}{|c|}{ Year } & \multicolumn{1}{c|}{ Source } & \multicolumn{1}{c|}{ Remarks } \\
\hline \multirow{2}{*}{ Khudi (0802) } & Temperature & $1987-2015$ & DHM & Daily data \\
\cline { 2 - 5 } & Rainfall & $1987-2015$ & DHM & Daily data \\
\hline Kuncha (0807) & Temperature & $1987-2015$ & DHM & Daily data \\
\hline $\begin{array}{l}\text { Gharedhunga } \\
(0823)\end{array}$ & Rainfall & $1987-2015$ & DHM & Daily data \\
\hline
\end{tabular}




\section{Field observation}

Direct observation was made in three CFUGs for additional information and field verification to observe the local adaptation measures. Observation was made in Kirepani CFUG to observe eroded land in the sloppy area, Jagreni CFUG to observe dry, harsh agricultural land and Kalika CFUG to observe forest area mainly affected by forest fire. The observation was aimed to identify impact of climate change in community forest area.

\section{Data analysis}

The indicators of climate change were analysed in five levels - highly increasing (5), increasing (4), same as before (3), decreasing (2) and highly decreasing (1). Similarly, seven statements were asked to the same respondents so that their responses could further support our results in five levels again. The statements on impacts of climate change were analysed in five levels i. e., strongly agree (5), agree (4), same as before (3), disagree (2) and strongly disagree (1). The analysis was done on the basis of caste, gender, age-group and economic class also.

Climatic data (temperature and rainfall) acquired from the DHM was entered in Microsoft Excel 2010 and presented through trend lines. Least squares curve fitting technique was used to find a linear trend in the data. The linear trend between the time series data $(y)$ and time $(t)$ is given in the equation below.

$y=a+b t$

Where, $\mathrm{y}=$ temperature or rainfall, $\mathrm{t}=$ time (year), "a" and "b" the constants estimated by the principle of least squares) (Practicle Action Nepal, 2009). Similarly, the Likert scale test was used for analysis of perceptions of the respondents of CFUGs on the climate change and its impacts.

\section{Likert Scale Test}

$$
\begin{aligned}
\mathrm{SI} & =\sum_{\bar{N}}^{\frac{F i}{N}} \\
& =\frac{\text { Number of votes } \times \text { weight for each column }}{\text { Total number of votes }}
\end{aligned}
$$

Where,

$\mathrm{SI}=$ Satisfaction index

$\mathrm{Fi}=$ Frequency of scale

$\mathrm{N}=$ Number of responses
Five responses (strongly agree, agree, same as before, disagree, strongly disagree) were rephrased and their satisfaction index was calculated. For example, the number of responses who strongly agreed for all the climatic indicators, caste, economic class, age-group and gender were calculated separately for each term. It was multiplied by the weight of each column, which we had selected $(5,4,3,2$, and 1$)$ and then divided by the total number of votes or respondents in the area. The obtained satisfaction index value for each column were summed and finally calculated the weighted mean.

\section{Weighted mean $=\sum S I$}

On the basis of calculated weighted mean, we concluded our results. Any climatic indicator with the highest weighted mean referred to the strong feeling of the respondents on it. The same process was followed for all the criteria and statements.

\section{Results and discussion}

\section{CFUGs knowledge of climate change}

\section{Understanding climate change: It's meaning and causes}

Majority of the community forest users (CFUs) had heard the term climate change, however, understanding of the term by the respondents varied (Fig. 2), which are as follows:

- Longer drought period for growing agricultural crops $(69.35 \%)$

- Decrease in monsoon rainfall season $(59.68 \%)$

- Drying of water sources (53.23\%),

- Increase in winter temperature (32.26\%)

- Unusual change of nature (24.19\%)

- Increasing pollution in environment $(16.13 \%)$ 


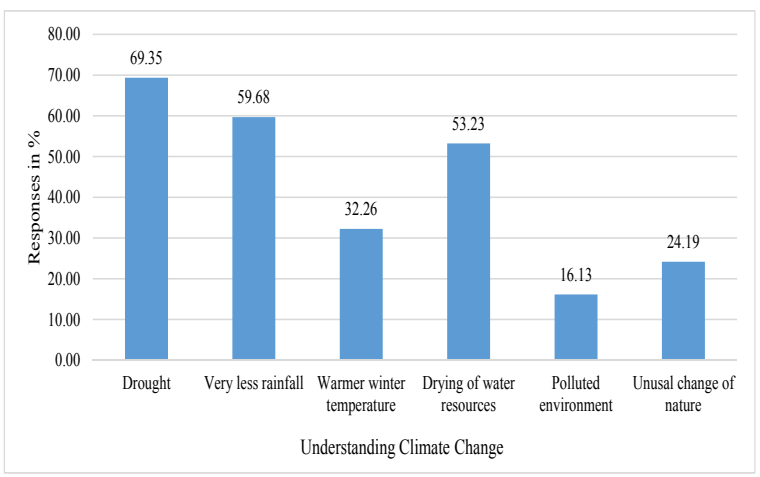

Fig. 2: Understanding climate change: Its meaning and causes

It seems that CFUs interpreted the term 'climate change' based on the particular climatic event they normally faced in their areas. Ninety per cent of the respondents believed that the climate change was due to increased drought period and drying of water sources. Likewise, FGD concluded that media has played supportive role to capacitate the users. The major sources of gaining knowledge on climate change and its impacts, the process of mitigation and adaptation with the current situations were through television, radios, workshops/seminars conducted by different organizations, such as CARE Nepal, District Forest Office, District Soil Conservation Office.

Likewise, $75 \%$ of the total respondents agreed that human beings were responsible for the climate change. People are responsible for climate change by deforestation, poor management of the waste products, firewood burning, establishing the industries and increasing vehicles. IPCC fifth assessment report explicitly revealed that human influence has impacted climate system (IPCC, 2014). Respondents felt that the winter temperature is increasing in a rapid way, incident of drought is increasing, rainfall pattern is unpredictable, seasons are changing, hail storm occurs abnormally, water sources are decreasing, wind storm is getting stronger, changes in flowering and fruiting time, invasion of new plant species e.g Lantana camara (Dahal, 2009) and reduction of some indigenous flora and fauna (Regmi et al. 2008 cited in Manandhar and Schmidt, 2011). According to similar study in India and
Ilam district, Nepal (Chaudhary and Bawa, 2011), there is a widespread feeling of warmer weather, drying water sources and the onset of summer and monsoon has advanced during the last ten years. According to Dhruba Dev Joshi, President of Kalika CFUG, previously owl, black-capped bulbul (jureli- Pycnonotus melanicterus), etc. were commonly found, but now they are not seen in the area. Increased dryness is due to increase in drought in premonsoon season, which has exposed forest for wild fire. They also shared their experiences that there used to be Maghe Jhari (rainfall in Magh month) in Magh (from mid-February to mid-March) previously and it used to be very cold. But, nowadays, there is not a drop of rain in that month and days are being warmer due to increase in temperature. Likewise, people used to know the time for starting to grow maize in their land when there was leaf fall from Ficus lacor (locally known as kabhro) tree. But now people are observing multiple incidents of leaves falling from this tree, which is not normal for this species and it has created uncertainty of time for growing maize. The impact of climate change is in biodiversity and agriculture like early budburst and flowering, new agricultural (Chaudhary and Bawa, 2011) pests and weeds, etc. as per the community knowledge. At present, CFUs are experiencing drought as a major climatic hazard, due to which there was gradual reduction in crop production and income sources as well, loss of local land races of both crops and domestic animals, changes in cropping sequences, drying up of wells, and increasing incidences of disease and pest (Regmi et al. 2008 cited in Manandhar and Schmidt, 2011).

\section{Perception on the indicators of climate change}

The community had noticed different indicators of climate change. Among the discussed major six climatic indicators with the respondents, drought frequency ranked the first. Similarly, temperature ranked the second and forest fire ranked the third (Table 5). These results indicated that increase in drought frequency, temperature and fire frequency are more responsible in impacts of climate change. 
Table 5: Perception of the CFUGs based on climatic indicators

\begin{tabular}{|l|l|c|c|c|c|c|c|c|}
\hline S.N. & Indicators & $\begin{array}{c}\text { Highly } \\
\text { Increasing }\end{array}$ & Increasing & $\begin{array}{c}\text { Same } \\
\text { as } \\
\text { before }\end{array}$ & Decreasing & $\begin{array}{c}\text { Highly } \\
\text { Decreasing }\end{array}$ & $\begin{array}{c}\text { Wt. } \\
\text { Mean }\end{array}$ & Rank \\
\hline 1 & Temperature & 1.69 & 2.13 & 0.29 & 0.06 & 0 & 4.17 & II \\
\hline 2 & Water sources & 0 & 0.13 & 0.48 & 1.19 & 0.21 & 2.01 & VI \\
\hline 3 & $\begin{array}{l}\text { Forest fire } \\
\text { frequency }\end{array}$ & 0 & 1.35 & 1.35 & 0.42 & 0 & 3.12 & III \\
\hline 4 & $\begin{array}{l}\text { Flood } \\
\text { frequency }\end{array}$ & 0 & 1.48 & 1.06 & 0.55 & 0 & 3.09 & IV \\
\hline 5 & $\begin{array}{l}\text { Drought } \\
\text { frequency }\end{array}$ & 1.85 & 2.13 & 0.24 & 0.05 & 0 & 4.27 & I \\
\hline 6 & $\begin{array}{l}\text { Variation in } \\
\text { river flow }\end{array}$ & 0 & 0.45 & 0.34 & 1.23 & 0.16 & 2.18 & V \\
\hline
\end{tabular}

The first, second and third ranking of the statements were incidences of drought during rainy season, the annual rainfall not supporting the crop production as before, and drying up of natural water resources, respectively (Table 6).

Most of the respondents agreed that water bodies are highly affected by the climate change followed by natural water resources are drying up. Though, they agreed that there is change in water level of the rivers but they were not much agreed on increase in river flow over a period of time. Majority of the respondents agreed that the programme related to conservation and management of water resources and climate change adaptation is necessary. According to Haque et.al (2012) climate variability is perceived to have changed and resulted to increase in climate variability sensitive diseases, human health issues and agricultural problems and livelihood.

Table 6: Perception on the basis of agreed statements

\begin{tabular}{|c|c|c|c|c|c|c|c|c|}
\hline S.N. & Statements & 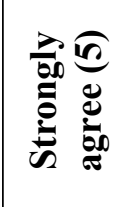 & 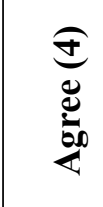 & 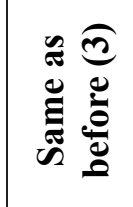 &  & 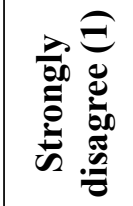 & 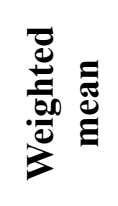 & 气ี \\
\hline 1 & $\begin{array}{l}\text { The weather is becoming dry due to } \\
\text { climate change }\end{array}$ & 3.06 & 0.52 & 0.24 & 0.19 & 0.06 & 4.07 & V \\
\hline 2 & $\begin{array}{l}\text { Natural water resources (ponds) are } \\
\text { drying up }\end{array}$ & 2.9 & 0.77 & 0.19 & 0.23 & 0.05 & 4.14 & III \\
\hline 3 & $\begin{array}{l}\text { Highly decrease in grasslands due to } \\
\text { rise in temperature and evaporation rate }\end{array}$ & 2.58 & 0.71 & 0.39 & 0.19 & 0.08 & 3.95 & VI \\
\hline 4 & $\begin{array}{l}\text { The annual rainfall is not supporting } \\
\text { the crop production as before }\end{array}$ & 2.74 & 1.09 & 0.19 & 0.16 & 0.03 & 4.21 & II \\
\hline 5 & $\begin{array}{l}\text { Incidences of drought have been } \\
\text { increased during rainy season }\end{array}$ & 3.06 & 0.84 & 0.29 & 0.13 & 0.02 & 4.34 & I \\
\hline 6 & $\begin{array}{l}\text { Climate change has led to the decline } \\
\text { of forest resources }\end{array}$ & 2.74 & 0.9 & 0.29 & 0.13 & 0.05 & 4.11 & IV \\
\hline 7 & $\begin{array}{l}\text { Climate change is likely to bring } \\
\text { various diseases in the community }\end{array}$ & 1.69 & 0.26 & 0.97 & 0.23 & 0.16 & 3.31 & VII \\
\hline
\end{tabular}




\section{Differential impact of climate change}

The impact of climate change is on the basis of caste, gender, age-group and economic class also.

The first ranking of Dalit indicated that they were highly affected by the climatic hazards like floods, landslides, drought, etc. which is followed by Janajati and BCT (Table 7).

Table 7: Impacts of climate change by caste

\begin{tabular}{|c|c|c|c|c|c|c|c|c|}
\hline S.N. & Caste & 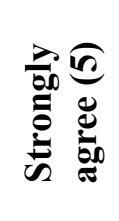 & 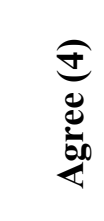 & 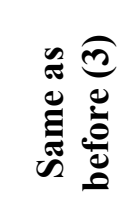 & 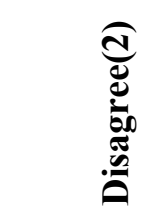 & 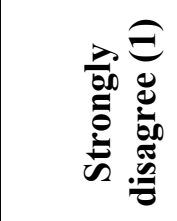 & 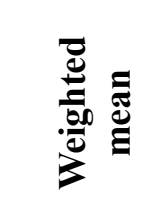 & 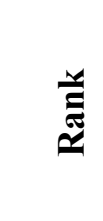 \\
\hline 1 & Dalit & 3.23 & 0.65 & 0.24 & 0.16 & 0.03 & 4.31 & I \\
\hline 2 & Janajati & 1.21 & 1.29 & 0.97 & 0.16 & 0.03 & 3.66 & II \\
\hline 3 & BCT & 0.81 & 0.97 & 1.45 & 0.16 & 0.03 & 3.42 & III \\
\hline 4 & Others & 0.56 & 0.65 & 1.11 & 0.48 & 0.11 & 2.91 & IV \\
\hline
\end{tabular}

Single women were highly affected by the impacts of climate change, which is followed by women and girls (Table 8). Similar study showed that poor and women, in particular, are highly

Table 8: What different categories of female thinks about impacts of climate change?

\begin{tabular}{|l|l|l|l|l|l|l|l|l|}
\hline S.N. & $\begin{array}{l}\text { Categories of } \\
\text { female }\end{array}$ & $\begin{array}{l}\text { Strongly } \\
\text { agree (5) }\end{array}$ & $\begin{array}{c}\text { Agree } \\
\text { (4) }\end{array}$ & $\begin{array}{c}\text { Same as } \\
\text { before (3) }\end{array}$ & Disagree (2) & $\begin{array}{c}\text { Strongly } \\
\text { disagree (1) }\end{array}$ & $\begin{array}{c}\text { Weighted } \\
\text { mean }\end{array}$ & Rank \\
\hline 1 & Women & 2.42 & 0.65 & 0.73 & 0.09 & 0.06 & 3.95 & II \\
\hline 2 & Girls & 0.81 & 0.97 & 1.21 & 0.32 & 0.03 & 3.34 & III \\
\hline 3 & Single Women & 3.23 & 0.97 & 0.24 & 0.03 & 0.02 & 4.49 & I \\
\hline
\end{tabular}

vulnerable to climate change due to their high levels of poverty, their dependence on natural resources and their already high exposure to floods, landslides and drought in mountain region (Dahal, 2009). Respondents also shared that water scarcity has hit hard to poor households and increased the workload of women.

The people in old age group were mostly affected by the impacts of climate change, which is followed by the people in young age-group and middle age-group (Table 9).

Table 9: Impacts of climate change by age-group

\begin{tabular}{|l|l|l|l|l|l|l|l|l|}
\hline S.N. & $\begin{array}{c}\text { Age } \\
\text { group }\end{array}$ & $\begin{array}{c}\text { Strongly } \\
\text { agree (5) }\end{array}$ & Agree (4) & $\begin{array}{c}\text { Same as } \\
\text { before (3) }\end{array}$ & $\begin{array}{c}\text { Disagree } \\
\text { (2) }\end{array}$ & $\begin{array}{c}\text { Strongly } \\
\text { disagree (1) }\end{array}$ & $\begin{array}{c}\text { Weighted } \\
\text { mean }\end{array}$ & Rank \\
\hline 1 & $\begin{array}{l}\text { M i d d le } \\
\text { age }\end{array}$ & 0.81 & 0.97 & 0.97 & 0.48 & 0.03 & 3.26 & III \\
\hline 2 & Young & 1.45 & 0.77 & 0.82 & 0.42 & 0.03 & 3.49 & II \\
\hline 3 & Old & 3.22 & 0.65 & 0.24 & 0.16 & 0.03 & 4.3 & I \\
\hline
\end{tabular}

On the basis of economic class, ultra-poor people of any caste, gender, or age class, were highly affected by the impacts of climate change. Then, poor people were in second ranking, followed by medium and well off people in third and fourth ranking, respectively (Table 10). 
Table 10: Impacts of climate change on the basis of economic class

\begin{tabular}{|l|l|c|c|c|c|c|c|c|}
\hline S.N & $\begin{array}{c}\text { Economic } \\
\text { class }\end{array}$ & $\begin{array}{c}\text { Strongly } \\
\text { agree (5) }\end{array}$ & $\begin{array}{c}\text { Agree } \\
\mathbf{( 4 )}\end{array}$ & $\begin{array}{c}\text { Same as } \\
\text { before (3) }\end{array}$ & $\begin{array}{c}\text { Disagree } \\
\text { (2) }\end{array}$ & $\begin{array}{c}\text { Strongly } \\
\text { disagree (1) }\end{array}$ & $\begin{array}{c}\text { Weighted } \\
\text { mean }\end{array}$ & Rank \\
\hline 1 & Ultra-poor & 3.63 & 0.65 & 0.16 & 0.13 & 0 & 4.57 & I \\
\hline 2 & Poor & 2.02 & 1.29 & 0.73 & 0 & 0.03 & 4.07 & II \\
\hline 3 & Medium & 0.81 & 0.97 & 1.69 & 0.03 & 0.02 & 3.52 & III \\
\hline 4 & Well off & 0.4 & 0.65 & 1.45 & 0.32 & 0.27 & 3.09 & IV \\
\hline
\end{tabular}

Climate change impact will vary according to age, social class, occupation and gender (Haque et. al, 2012) and within poor, particularly, women will be affected (Stott, 2010). The results further support the finding of previous research (Gentle et al., 2014) that climate change vulnerability differs in terms of exposure, sensitivity and adaptive capacity across different well-being groups, gender, age and household location.

\section{Comparison between local people's perceptions of changes in temperature and rainfall}

\section{Variation in temperature}

The overall trend of mean annual maximum, minimum and average temperature recorded at Khudi Meteorological station from 1987 to 2015 showed an increment by $0.056{ }^{\circ} \mathrm{C}, 0.01{ }^{\circ} \mathrm{C}$ and $0.03^{\circ} \mathrm{C}$, respectively (Fig. 3). Similar analysis of climatic data (1976 - 2005) showed the highest trend (Practical Action Nepal, 2009) of mean temperature with more than $0.06^{\circ} \mathrm{C} /$ year. The trend of increase in temperature was high in pre-monsoon season and low in winter season. It indicated that summer is getting longer and hotter. Most of the common perceptions of the community on climate change are that the winter temperature is highly increasing and its duration becomes short as well, and water sources are drying. It means that the annual rainfall is highly decreasing in the study area. These results are in line with the results from the climatic data of DHM. It showed that general increase in hotness and decrease in coldness of the study area.

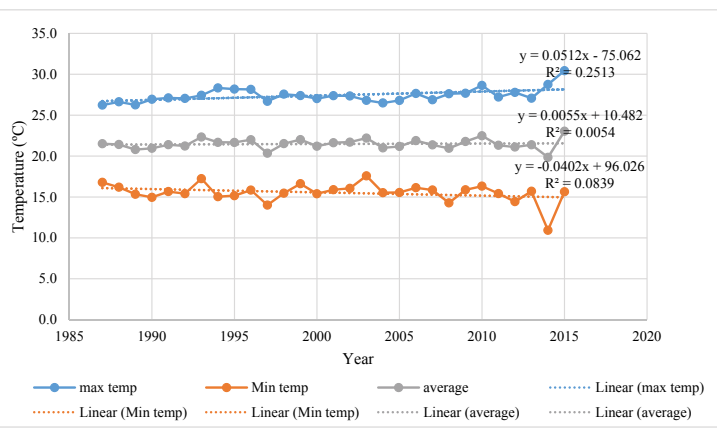

Fig. 3: Trend of mean annual maximum, minimum and average temperature at Khudi met. station (1987-2015)

Similarly, the trend of rainfall and temperature in three meteorological stations is presented in Table 11.

\section{Variation in rainfall}

The trend analysis of annual rainfall was based on the data recorded for a period of 29 years (19872015 ) at three stations. The rate of annual rainfall was found to be decreased over a period of 29 years at Khudi and Gharedhunga meteorological stations, which were $25.8 \mathrm{~mm}$ and $16.42 \mathrm{~mm}$, respectively. But the rate of annual rainfall was increased at Kuncha meteorological station (Table 11, Figs. 4, 5 and 6). The Khudi and Gharedhunga meteorological stations are closer to the study area, so we can conclude that the study area has negative trend of rainfall.

Table 11: Trend of rainfall and temperature in three meteorological stations

\begin{tabular}{|l|l|l|}
\hline Station & Variation in rainfall & Variation in temperature \\
\hline Khudi Met. Station & Decreasing at $25.8 \mathrm{~mm}$ per year & Rising at $0.03^{\circ} \mathrm{C}$ per year \\
\hline Kuncha Met. Station & Increasing at $2.82 \mathrm{~mm}$ per year & NA \\
\hline Gharedhunga Met. Station & Decreasing at $16.42 \mathrm{~mm}$ per year & NA \\
\hline
\end{tabular}




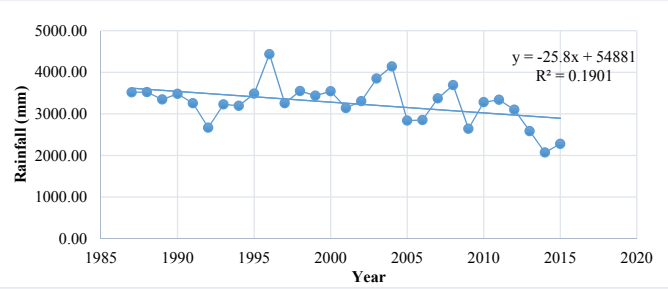

Fig. 4: Average annual trend of rainfall at Khudi Met. Station (1987-2015)



Fig. 5: Average annual trend of rainfall at Kuncha Met. Station (1987-2015)

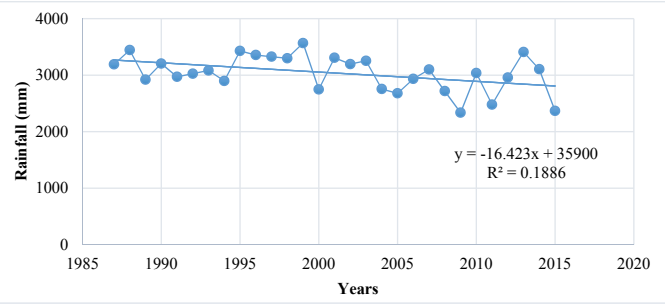

Fig. 6: Average annual trend of rainfall at Gharedhunga Met. Station (1987-2015)

We found that the highest decrease in rainfall was in Monsoon season, which was at the rate of $17.60 \mathrm{~mm} /$ year (Table 12). Due to late in monsoon, people were compelled to leave their agricultural land fallow. Crop production was found to be decreased due to drying of water sources. According to the respondents, at present the monsoon rainfall is with higher intensity and large quantity in a short period, which has washed away fertile land and crops.

Table 12: Comparison of trend of rainfall in different seasons

\begin{tabular}{|l|l|l|l|}
\hline S.N & Season & Year & $\begin{array}{l}\text { Trend of rainfall } \\
\text { in } \mathbf{~ m m}\end{array}$ \\
\hline 1 & Winter & $\begin{array}{l}1987- \\
2015\end{array}$ & -2.93 \\
\hline 2 & $\begin{array}{l}\text { Pre- } \\
\text { monsoon }\end{array}$ & $\begin{array}{l}1987- \\
2015\end{array}$ & -4.02 \\
\hline 3 & Monsoon & $\begin{array}{l}1987- \\
2015\end{array}$ & -17.60 \\
\hline 4 & $\begin{array}{l}\text { Post- } \\
\text { monsoon }\end{array}$ & $\begin{array}{l}1987- \\
2015\end{array}$ & -0.42 \\
\hline
\end{tabular}

\section{Conclusion}

Most of the respondents have perceived climate change personally and they are aware that climate change is happening through various sources and impacting them in different means and media. The impact of climate change is more for ultra-poor communitydue to high levels of poverty, their dependence on natural resources and high exposure to floods, landslides and drought and lower adaptive capacity. In addition, dalit, marginalised Janajati, and another group of people are further vulnerable and at risk as a result of ongoing poverty, inequality, and marginalisation. Furthermore, the study indicated that climate change, particularly increase in mean and maximum temperature and decrease in rainfall greatly influence the experiences and perceptions of the local people regarding climate change and related events. The understanding and perceptions of climate change of CFUGs and sharing their experiences related to climate change are very important for climate change adaptation and its planning. As users have already geared towards implementing adaptation activities in CFUGs, it is necessary to implement specific area focus programme for better targeting the activities and addressing the differential impact on biodiversity and livelihoods.Moreover, we need to acknowledge the role of forest in climate change adaptation and treat adaptation as part of development; considering forest management as a part of climate change adaptation is crucial.

Thus, we suggest that climate change impact should not be generalised rather it should be critically analysed and link with gender, youth, caste/ ethnicity and well-being in dealing with the climate change impact and adaptation planning. Awareness and adaptation initiatives should thus be conducted focusing on climate change scenarios, its potential risk and adaptation measures to be adopted with considering socio-economic specifications of the community. The policy should ensure and focus on capacity enhancement of more vulnerable and marginalised community. Thus this study provides baseline information and knowledge regarding the local community forest user group's perceptions of climate change and their impacts to help reinforce local adaptation. This kind of information is useful for policymakers who need to understand and facilitate climate change adaptation strategies at a local level in the rural areas of Lamjung as well as in other places of the country. 


\section{References}

Anderegg, W. R. L., Kane, J. M. and Anderegg, L. D. L. 2013. Consequences of widespread tree mortality triggered by drought and temperature stress. Nature Climate Change 3 (1): 30-36. https://doi.org/10.1038/ nclimate1635.

Baral, J. C. 2011. Climate change adaptation in Nepal- An overview of the initiatives and impending issues. The Nepal Journal of Forestry14 (1): 75-84.

CBS. 2011. Population Statistics of Nepal. Central Bureau of Statistics (CBS), Kathmandu, Nepal.

Chaudhary, P. and Bawa, K. S. 2011. Local perceptions of climate change validated by scientific evidence in the Himalayas. Biology Letters, rsb120110269.

Dahal, N. 2009. Impact of climate change on forests and livelihoods: issues and options for Nepal. Livelihoods and Forestry Programme.

DDRC. 2011. Disaster Preparedness and Response Plan. District Disaster Relief Committee (DDRC) District administration Office, Lamjung, Nepal.

Deressa, T. T., Hassan, R. M. and Ringler, C. 2011. Perception of and adaptation to climate change by farmers in the Nile basin of Ethiopia. The Journal of Agricultural Science 149 (1): 23-31.

Dhungana, N., Khadka, C., Bhatta, B., \& Regmi, S. (2017). Barriers in Local Climate Change Adaption Planning in Nepal. JL Pol'y\& Globalization, 62: 20-24.

DoF. 2018. Hamro Ban. Ministry of forest and Soil Conservation, Babarmahal, Kathmandu, Nepal.

Garg, A., Shukla, P. R. and Kapshe, M. 2007. From climate change impacts to adaptation: A development perspective for India. Natural Resources Forum 31 (2): 132-141.
Gentle, P., Thwaites, R., Race, D. and Alexander, K. 2014. Differential impacts of climate change on communities in the middle hills region of Nepal. Natural Hazards 74 (2): 815-836.

Haque, M. A., Yamamoto, S. S., Malik, A. A. and Sauerborn, R. 2012. Households' perception of climate change and human health risks: A community perspective. Environmental Health 11 (1): 1-12.

IPCC. 2014. Summary for Policymakers: Working Group Contribution I, II and III to the IPCC Fifth Assessment Report of the Intergovernmental Panel on Climate Change [Core writing team, (eds.) Panchauri, R. K. and Meyer, L. A.]. IPCC, Geneva, Switzerland.

IPCC. 2007. Climate Change 2007: Adaptation and Vulnerability, summary for policy makers, Intergovernmental Panel on Climate Change, Geneva, Switzerland.

Keenan, R. J., Reams, G. A., Achard, F., de Freitas, J. V., Grainger, A. and Lindquist, E. 2015. Dynamics of global forest area: Results from the FAO Global Forest Resources Assessment 2015. Forest Ecology and Management 352: 9-20. https://doi. org/10.1016/j.foreco.2015.06.014

Manandhar, S., Vogt, D. S., Perret, S. R. and Kazama, F. 2011. Adapting cropping systems to climate change in Nepal: Acrossregional study of farmer's perception and practices. Regional Environment Change 11: 335-348.

Manandhar, S. and Schmidt, D. 2011. Adapting cropping systems to climate change in Nepal: a cross-regional study of farmers' perception and practices. Regional Environmental Change 11 (2): 335-348. https://doi.org/10.1007/s10113-010-0137-1

MoE. 2010a. Climate Change Vulnerability Mapping for Nepal. Ministry of Environment, Singh Durbar, Kathmandu, Nepal. 
MoE. 2010b. National Adaptation Programme of Action to Climate Changes. Ministry of Environment, Singh Durbar, Kathmandu, Nepal.

MoE. 2011. Climate Change Policy of Nepal. Ministry of Environment, Singh Durbar, Kathmandu, Nepal.

Practical Action Nepal. 2009. Spatial and temporal variability of climate change over Nepal (1976-2005). Kathmandu, Nepal.

Shrestha, S., Shrestha, U. B. and Bawa, K. 2018. Socio-economic Factors and Management Regimes as Drivers of Tree Cover Change in Nepal. PeerJ, 6, e4855. https://doi. org/10.7717/peerj.4855

Smith, B., Burton, I., Klein, R. J. and Wandel, J. 2000. An anatomy of adaptation to climate change and variability. Climatic change 45 (1): 223-251.
Stapp, J. R., Lilieholm, R. J., Leahy, J. and Upadhaya, S. 2016. Linking Attitudes, Policy, and Forest Cover Change in Buffer Zone Communities of Chitwan National Park, Nepal. Environmental Management 57 (6): 1292-1303. https://doi.org/10.1007/ s00267-016-0682-6.

Stapp, J. R., Lilieholm, R. J., Upadhaya, S. and Johnson, T. 2015. Evaluating the impacts of forest management policies and community-level institutions in the Buffer Zone of Chitwan National Park, Nepal. Journal of Sustainable Forestry 34 (5): 445-464. https://doi.org/10.1080/1054981 $\underline{1.2015 .1025080}$

Stott, R. 2010. Population and climate change: moving toward gender equality is the key. Journal of Public Health 32 (2): 159160. 